\title{
RUDERAL ECOLOGIES: Rethinking Nature, Migration, and the Urban Landscape in Berlin
}

\author{
BETTINA STOETZER \\ Massachusetts Institute of Technology \\ (iD http: / / orcid.org/0000-0002-6719-620X
}

There is a small plot of land at the edge of Kreuzberg, in what was once West Berlin, that has a peculiar story. This is how the story goes: in 1983, Osman Kalin had just quit his job. Having been a construction worker for many years, he struggled with back problems, which forced him into early retirement. Yet he soon got bored, and felt ready for a construction project of a different kind. Living a few blocks from the Berlin Wall, one day, he discovered a small triangle of land in the wall's shadow, littered with garbage. Osman cleared it and began to grow onions, tomatoes, and cabbage on it. As time went on, he added cucumbers, garlic, beans, sunflowers, and collard greens. With his wife he built a hut that soon developed into a two-floor shack, cobbled together from found objects. Months later, just when the tomatoes began to ripen, two East German border guards knocked at Osman's door. His garden, it turned out, was located on GDR territory: the East German government had constructed the wall in a straight line to save money, instead of following the zigzag contours of the actual border, thus skipping the triangle of land on which Osman's vegetables were now thriving. After endless negotiations, the GDR government allowed Osman to stay-provided his sunflowers did not grow taller than the Berlin Wall. 
In 1989, the wall tumbled and Osman's garden was no longer situated in an abandoned corner, but in the center of a unified city. When the new district office protested the garden dwelling, Osman insisted that the East German state had entrusted the piece of land to him. In the end, the dismal state of Berlin's finances benefited his cause, and plans to relandscape the former border zone into a green strip did not immediately materialize. Once again, Osman's garden was left alone.

Today, people affectionately call the garden the Berlin tree house (Baumhaus) or gecekondu - a reference to the squatter houses in Turkish cities whose name literally means "places built overnight" and whose courtyards and trees bear a resemblance to the structure of Anatolian villages. ${ }^{1}$ Not unlike the Turkish gecekondu, the Berlin version today features a small orchard of apricot, apple, pear, and plum trees. A large tree of heaven, once a small shrub growing in the cracks of the sidewalk, is now an integral part of the gecekondu's front wall. Each year, as the trunk expands, Osman cuts further into the wall to accommodate its growth.

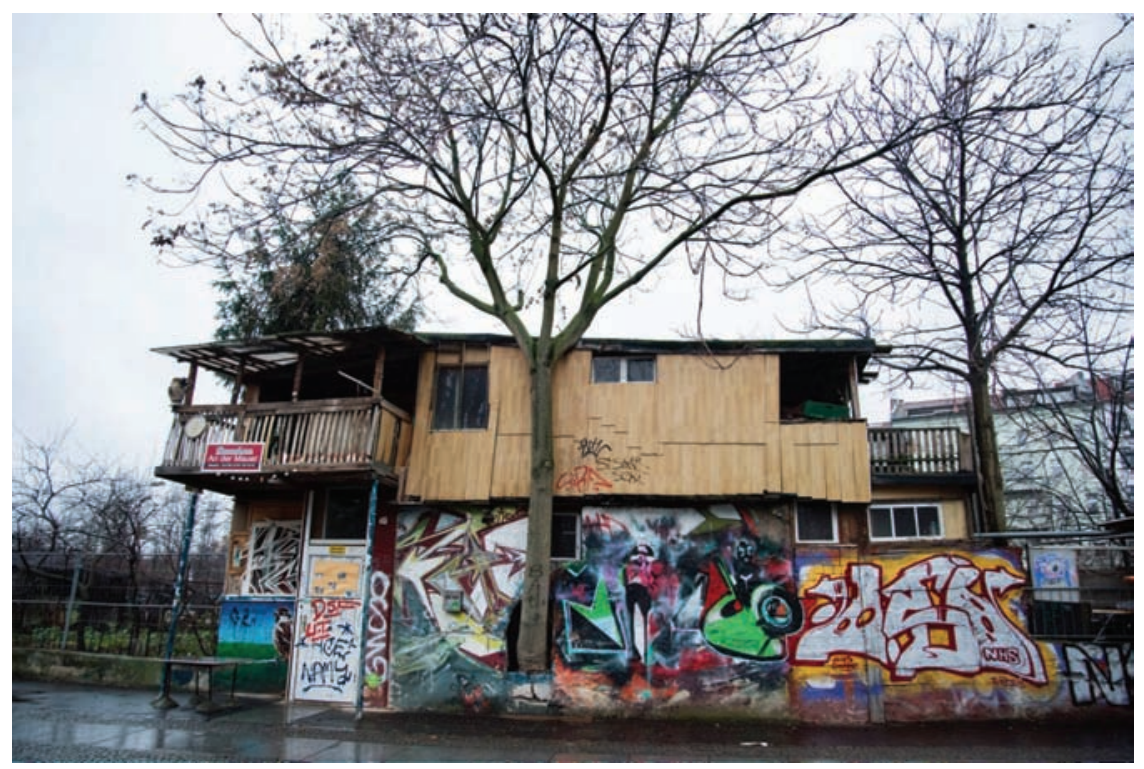

Figure 1. The Berlin gecekondu, with tree of heaven (Ailanthus altissima), Berlin, January 2017. Photo courtesy of Hank von Hellion.

The Berlin gecekondu is well known among Berliners and as far afield as Istanbul, where news reporters have chuckled about Osman's clever dealings. 
Sometimes, on the weekends, a tourist group stops by. Osman put a few chairs and a table in front of the garden shack to welcome occasional visitors from the neighborhood. When the table was stolen one day, Osman quickly replaced it. Its legs are now cemented to the ground.

I begin this essay with the story of the Berlin gecekondu to introduce the notion of the ruderal. Nestled in a small gap in the city's border infrastructure, Osman Kalin's tree house took advantage of the state's desire to simplify and draw straight lines. Thus the garden's ecology filled a gap, both in Osman's life and in the gray zones of the nation-state. Cobbled together from dreams, thriving vegetables, weeds, and thrown-away furniture, the gecekondu captures what I call a ruderal ecology in the city.

The term ruderal comes from rudus, the Latin term for rubble. A common term in urban ecology, it refers to communities that emerge spontaneously in disturbed environments usually considered hostile to life: the cracks of sidewalks, the spaces alongside train tracks and roads, industrial sites, waste disposal areas, or rubble fields (Grime 1977). ${ }^{2}$ Neither wild nor domesticated, ruderal communities depend on what is known as an "edge effect" and the juxtaposition of contrasting environments in one ecosystem.

Ruderal worlds initially entered my fieldwork thanks to a particular person: Herbert Sukopp, a well-known Berlin urban ecologist, who, alongside other botanists, studied plants growing in Berlin's rubble after World War II. I met Sukopp at the official opening event for Berlin's first Urban Nature Day, which had been organized by the Berlin Senate in 2007. Through him, I first heard about ruderal plants, such as sticky goosefoot (Chenopodium botrys) and tree of heaven (Ailanthus altissima)_ plants that can still be found in Berlin today, including in Osman's garden. From our conversations since, as well as in my encounters with other Berliners, human and nonhuman, I learned a new way of seeing nature in the city.

Drawing on my fieldwork and the history of urban ecology in Berlin, this essay develops the notion of the ruderal as an analytical framework for rethinking the heterogeneity of urban life in the ruins of European nationalism and capitalism. Attending to ruderal worlds, I argue, can redirect ethnographic attention toward human-nonhuman relations that emerge spontaneously in inhospitable environments - and thus to often unnoticed, cosmopolitan yet precarious ways of remaking the urban fabric. Following them means never just telling one story; it calls for an analytical lens that combines environmental perspectives with ques- 
tions of migration, race, and social justice. Such a method of thinking across registers, I argue, proves salient at a historical moment in which several crises of inhabiting the world have proliferated, including increasing nationalisms, racism, and global climate change (see Hage 2017).

Employing a ruderal lens in my ethnographic writing has challenged me to juxtapose seemingly disparate stories and practices - from rubble plants growing in the ruins of war, to makeshift urban gardens that accommodate spontaneous vegetation in the shadow of the Berlin Wall, to the smoke emanating from Berlin's racialized debates about barbecuing and appropriate human-nature relations in the city. Engaging with a series of these practices, this essay explores the possibilities of a ruderal analytic for an anthropological inquiry into urban environments and their ruins: an analysis that examines not only unruly nonhuman life but also the broader, unintended ecologies of human-built structures and the multispecies worlds of which they become part. In short: an ecology of unexpected neighbors in the city.

In recent years, anthropologists and scholars across the human sciences have turned their attention toward an analysis of the built environment, its infrastructure and ruination. Highlighting how the physical networks of cities, such as roads, trains, water supply, waste and sewage systems, or electric grids enable social life and forms of urban governance, many ethnographies have opened up fresh perspectives on the relation between materiality, consciousness, and culture (Carse 2012; Larkin 2013; von Schnitzler 2013; Lowrie and Boyer 2014; Chalfin 2014; Fennell 2015; Anand 2017). This analytic shift has emerged at a historical moment when the earthly entanglements of anthropology's central subject, "man," and the limits and toxic effects of managing nature as resource have become increasingly visible (Fortun 2012). ${ }^{3}$ In an era of what some call the Anthropocene-an era in which humans have fundamentally changed the course of the earth's ecosystems (Chakrabarty 2012; Latour 2013) _ cultural analysts are reconceptualizing how human-nonhuman relations exceed Western dichotomies of nature and culture (Viveiros de Castro 2012; Descola 2013; de la Cadena 2015). This call for renewal carries a sense of urgency. In the face of climate change, the global circulation of toxins and waste, and the ordinariness of planetary environmental risk, anthropology it seems, has become a science of ruins (Masco 2008; Dawdy 2010; Navaro-Yashin 2012; Gupta 2013; Harms 2013; Johnson 
2013; Schwenkel 2013; Stoler 2013; Gordillo 2014), examining the dynamics of life on a damaged planet (Tsing 2015).

Although this scholarship attests to a common lens that examines the destruction and possibilities of modern world-making projects, infrastructures and ruins are often conceptualized separately from one another. ${ }^{4}$ As a result, an understanding of infrastructure as a substrate of human cultural systems can run the risk of assuming a vitalist dynamic, even as some scholars discuss infrastructure's failures, highlight "experimental ontologies" (Bruun Jensen and Morita 2017), or show how progress and ruination are intimately tied to one another (Johnson 2013). This vitalism depends on a gendered binary between technology and built environments as forms of externalization, on the one hand, and matter (or ruins) as passive or degenerate, on the other (Le Guin 1989).

In addition, the duality between infrastructure and ruins corresponds to a nature-culture divide in urban scholarship: nature has for a long time functioned as the constitutive outside, or other, of much urban social analysis, including urban anthropology. With the development of industrial society and the emergence of sociology and anthropology, the city, specifically the European metropole, became the locus of culture and progress, independent from the resources and labor of the countryside or the colony (Williams 1973; Cronon 1992). Although recent scholarship has challenged this divide by examining various ecologies of urbanism (Wolch 1998; Bennett and Teague 1999; Heynen, Kaika, and Swyngedouw 2006; Brantz and Dümpelmann 2011; Gandy 2013; Rademacher and Sivaramakrishnan 2013; Chalfin 2014; Anand 2017), urban analysis often continues to treat nature as a background of urban life, or as "a physical place where you can go" (Haraway 1992, 66), and thus risks seeing cities as being in control over or apart from the nonhuman.

The ruderal perspective I offer draws on ruins and infrastructure as conceptual devices to further undo the nature-culture divide in anthropological scholarship. While examining what it means to live with ruins (see also Tsing 2015), it pushes a ruin framework further by theorizing the urban and life in the rubble of nationalism and racial inequality. A ruderal lens thus combines an analysis of ruins and their emerging ecologies with questions of urban social justice. Inspired by approaches in feminist and critical race studies, this lens eschews what Kim Fortun $(2014,314)$ has called "the Latour effect" in anthropology and science studies: a singular focus on practices of expertise and actor networks in late industrialism that does not take a closer look at the material and social constitution of the toxic and inhospitable environments that make up people's lives today. In 
contemporary European cities, this means looking at the ways in which the ruinous effects of capitalism, racism, and nation-making become embodied in humanenvironment relations, beyond the boundaries of the human skin, in often unpredictable ways.

For the purposes of this essay, I will first attend to an instance in Berlin's history in which the urban fabric literally burst apart. It is in this moment, I argue, that the city emerged as more than human habitat, abundant with unexpected neighbors and illegal squatters (both human and nonhuman). This rupture gave rise to a view of the city in which nature is not simply out there to be managed and incorporated into anthropogenic landscapes via human infrastructures, but an unwieldy and integral part of the city - a ruderal city in which humans and nonhumans have coexisted (however violently) all along. ${ }^{5}$ If we go a step further and understand ruination (Stoler 2013) and rubble (Gordillo 2014) in the broad sense, not as separate from but as central to the urban environments we inhabit - built on social exclusions, capitalist urbanization, and profound environmental change - then, I suggest, the ruderal can serve as a guide to explore the lives that arise in their midst. Thinking with the ruderal, the goal is not to equate people with plants or other nonhumans, but to ask how people, plants, animals, and their environments connect and get entangled in modes of capital accumulation, in projects of nation-making, and in environmental destruction - and how they traverse them. Revisiting Berlin's postwar moment, I will reflect on the challenges that the notion of the ruderal city poses to the study of cities, and more generally, to a cultural analysis that examines the material and social dynamics of what it means to live on an increasingly inhospitable planet. In the second part of the essay, I will then address how a ruderal lens emerged in my fieldwork and guides my ethnographic writing about urban ecologies, migration, and displacement in Berlin.

\section{A CITY OF RUBBLE}

At the end of World War II, the city of Berlin lay in rubble. In their effort to bring the Nazi regime to a final halt, the Western allies bombed large parts of the city center. After intense ground battles between German and Soviet troops in the spring of 1945, large parts of the city's built environment were destroyed. Thousands of people had died on all sides; the city's infrastructure had torn apart; trees in parks and urban woodlands had burned down. Many people lived in makeshift shelters. Amid the destruction, images of Berlin as a feral city abounded. News of starving deer, wolves, and wild boar ravaging the city's outskirts in herds 
evoked a sense of Berlin "gone wild" (Davis 2002, 384). With it, a widespread sentiment unfolded: numbness. In A Natural History of Destruction, W. G. Sebald (2004) depicts this numbness as a key element of the social life of the bombed cities after fascism. Describing scenes of apathy amid a population living in ruins, Sebald shows how a sanitized knowledge of human suffering pervaded much of the public narrative about the postwar urban experience.

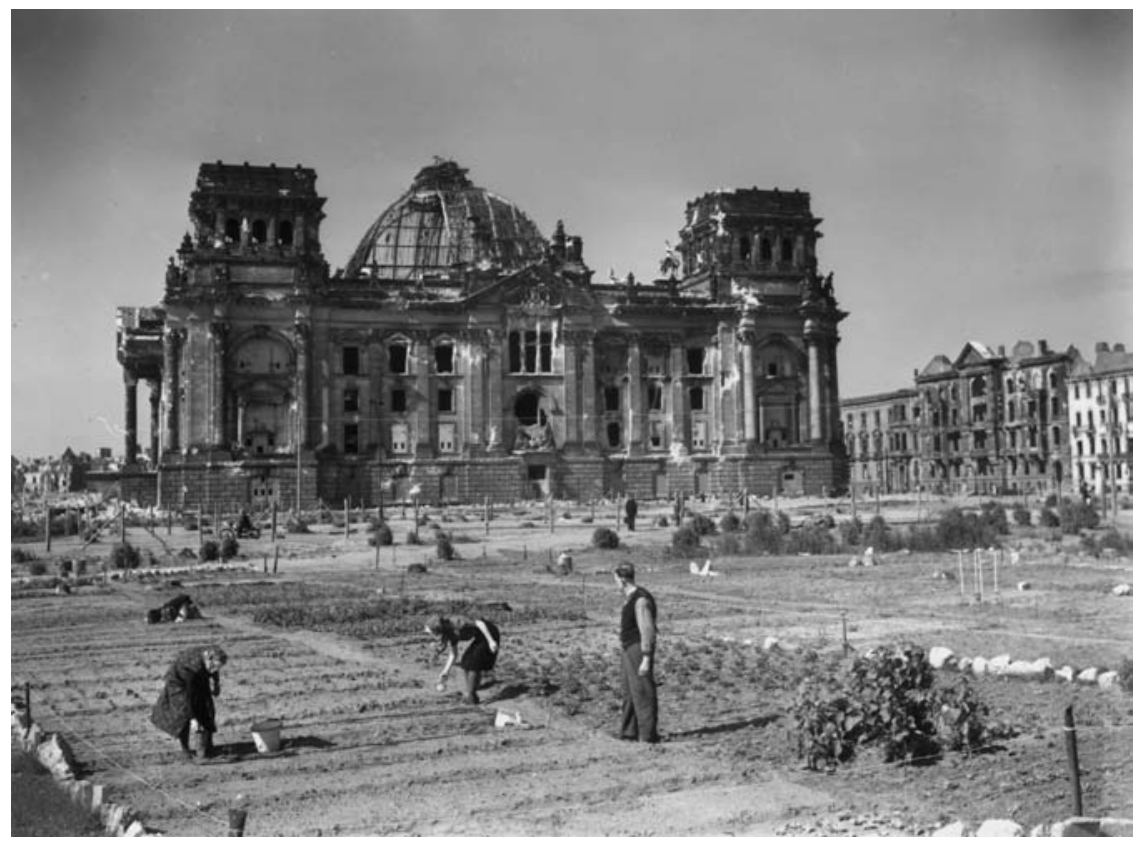

Figure 2. Berliners planting potato seedlings by the ruins of the Reichstag, Tiergarten, Berlin, May 1946. Photo by Fred Ramage, reproduced here courtesy of Getty Images.

In this context of urban breakdown, cultivating plants played an important role. Short of food, residents grew vegetables in the burnt and logged-down parks. Thousands of oak and birch trees were donated and brought from across the country via plane during the Berlin airlift to reforest the city's parks and forests. A new infrastructure of nature (Carse 2012) developed as the city became divided into two parts: East and West Berlin's municipal administrations hired thousands of workers - many of them women - to clear the streets from rubble and erase the traces of war and genocide. Paving the way for economic growth, large amounts of rubble were recycled to rebuild roads or landscaped into so-called rubble mountains. Today, Berlin's rubble mountains-fourteen of them altogether-appear as a natural part of the urban landscape. 
Greening the city's rubble and the notion of new life emerging from ruins thus formed key elements in the national imaginary after the war (Diefendorf 1993): "Rising from Ruins" ("Auferstanden aus Ruinen") became the title of East Germany's national anthem in 1949, and so-called rubble women entered the national imagination as heroic figures. In the 1950s, West Germany depicted the following image on its fifty-pfennig coin: a kneeling woman stooping over to plant an oak seedling. It commemorated both the rubble women and the women reforesting the logged-down urban and rural forests.

\section{THE UNRULY HETEROGENEITY OF NATURE IN THE CITY}

Yet despite this carefully managed nature returning to the city, Berlin's rubble had its own life. Due to the city's political division during the Cold War, large rubble fields dotted Berlin's center for decades and provided a habitat for many plants to flourish in the city for the first time. Intrigued by this new diversity, West Berlin botanists - both hobbyists and scientists - began to study the rubble vegetation in the 1950s and developed a different way of seeing nature in the city.

One of these botanists was Herbert Sukopp. Born in Berlin in 1930, he grew up in a landscape blasted by the bombings. As we sat sipping tea in his office at the Institute for Ecology at the Technical University Berlin, I asked him how he began studying the rubble's ecology. Pointing out that the city's rubble formed an integral part of his childhood, he responded: "How could I have studied anything other than rubble spaces?" Indeed, the construction of the Berlin Wall and the city's division created a new situation for West Berlin botanists: instead of traveling to their usual field sites in the countryside or as far away as Brazil, they were now literally walled off from their surroundings. In a city numbed by national reconstruction and an urge to move on, they re-envisioned the city as that which was new and unknown.

Researching the rubble flora, they discovered a city bustling with plants from all over the world. Usually considered weeds, these "newcomers" (Sukopp and Wurzel 2003, 72) hailed from warmer regions in the Mediterranean, Asia, and the Americas. Among them: sticky goosefoot (Chenopodium botrys), a Mediterranean plant, as well as a tree from China, the tree of heaven (Ailanthus altissima), the North American black locust (Robinia pseudo-accacia), and the herb giant goldenrod (Solidago giganteana), which all appeared widely in Berlin for the first time. But there were also plants like mugwort (Artemisia vulgaris) and a grass species of North American origin, Lindheimer's millet (Panicum lindheimeri). As 
ruderal plants, they prefer dry, gravelly soil and a warm climate. Their seeds had found their way into Berlin via diverse transport routes. Some of them had crossed the city on the boots of soldiers or refugees during the war, via packaging material from imported goods, or hay transported on wagons by the Russian army for horses. Other seeds' routes remained unknown.

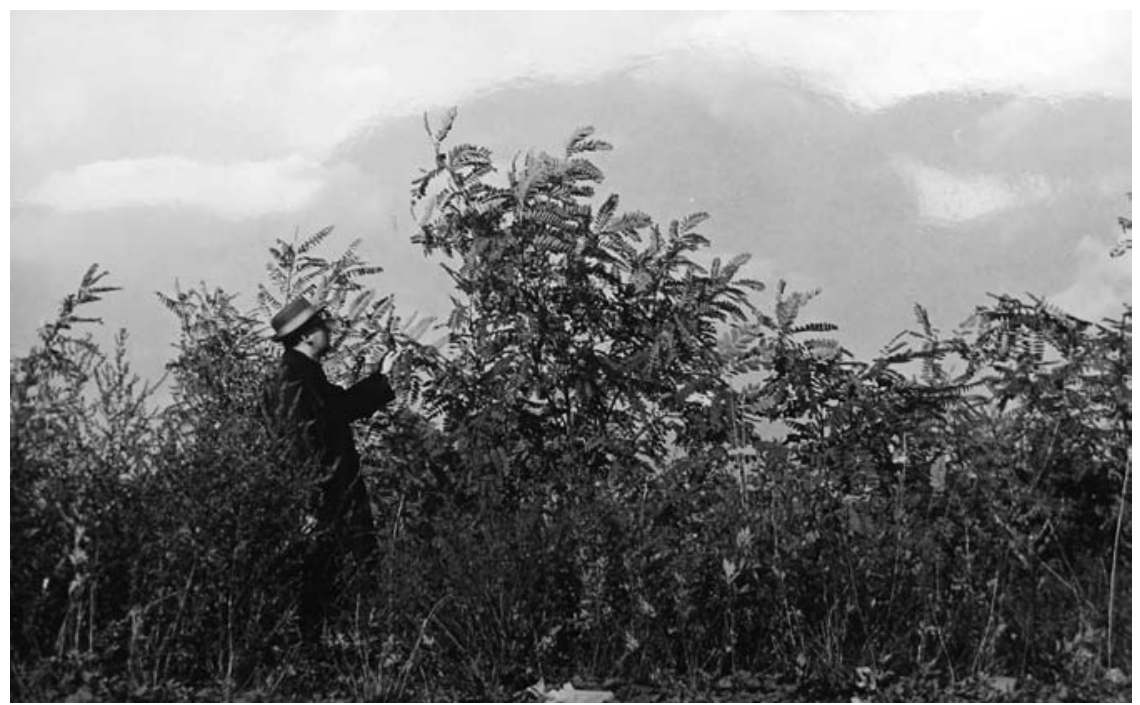

Figure 3. Herbert Sukopp, conducting research on ruderal vegetation in the 1950s in Berlin. Photo by Alexander Kohler.

Following the dispersal and ecology of ruderal plants throughout the city, a world of cosmopolitan connection and profound environmental change unfolded in front of the botanists' eyes. For example, the highest density of sticky goosefoot occurred in the bombed city center (Sukopp 2007, 62). Increasing trade, migration, and urbanization had created a diversification of habitats, and a new type of vegetation became visible: a ruderal vegetation spontaneously growing in rubble spaces, wastelands, and along the city's infrastructure. Its diversity mirrored the history of the city and ran "parallel to the size and intensity of trade and industry," thus being "a direct standard of the technical culture" (Sukopp 2008, 84).

Although some of the botanists made use of terms such as foreigners, aliens, and guests, thus engaging geographic imaginations that connected plants to a world of nations, borders, and immigration (Lachmund 2003, 245), ${ }^{6}$ they did not necessarily see ruderal plants as unwelcome intruders. The first to inhabit disturbed environments, ruderals were not a nuisance: they set the stage for other flourish- 
ing ecosystems, as by giving rise to spontaneous wetlands, attracting birds, or providing shade and organic matter important for other species. ${ }^{7}$ Ruderals were also not simply a sign of regenerating nature; they indicated the outcome of a much more ambivalent and radically changing urban ecology. The life cycles of sticky goosefoot and other plants revealed that Berlin, like other cities, had become hotter (Sukopp and Wurzel 2003, 70). Increased traffic, a densely built environment, and additional heat sources in the city and on Earth in general had led to a rise in Berlin's temperatures - sometimes up to $12^{\circ} \mathrm{C}$ in comparison to its surroundings. This greenhouse effect (see Sukopp 2003) had accelerated over the course of industrialization. Ruderals were thus indicators of global connections, a city coming back to life, and of global environmental change-and they were traces of the violence nationalism had wrought across Europe.

The encounter between botanists and ruderal plants led to the emergence of urban ecology as a new field of scientific inquiry and opened up new possibilities for including urban wastelands in city planning and conservation policies in enduring ways. ${ }^{8}$ But as Jens Lachmund $(2013,6)$ has shown, this view of the heterogeneity of urban nature, including subsequent biotope mappings, also created new hierarchies of value by differentiating urban habitats according to their degree of closeness to nature, thus losing some of its "initial political momentum." Yet despite this incorporation of ecological research into urban governance, I argue that the encounter between botanists and ruderal plants created an opening for the study of cities and cultural analysis more generally. With their unwieldy and sticky presence, ${ }^{9}$ rubble plants challenged botanists to account for ruderal life in the city beyond the value regimes of urban nature and culture. Neither wild nor domesticated, sticky goosefoot and its ruderal companions dwell alongside and in the cracks of urban infrastructures, including the categorical units of nature and culture through which we make sense of them. They are their unsolicited hitchhikers and invisible ecologies. Their presence demands a broader conversation about the unexpected consequences of anthropogenic landscapes, capitalist trade, and migration shaping urban environments — beyond a universalizing framework of the Anthropocene. Exceeding systems of human governance, Berlin's rubble fields were not passive environments but developed their own lives. Rather than constituting the cultivated nature of postwar urban planning or the native natures the fascist regime had dreamt of, they challenged the idea of a homogeneous nation and directed attention to previously unnoticed and cosmopolitan ways of remaking the urban fabric. In this ecology of unexpected neighbors, the story is never singular but always consists of multiple strands, and one does not know 
beforehand whether it will end up in destruction or enable flourishing. Let me thus elaborate how, in my research in Berlin, the ruderal has served as a guide to think across registers - of migration, capitalism, and the more-than-human.

\section{URBAN NATURE IN THE NEW BERLIN}

The period after the collapse of socialism and German unification constituted yet another fraught moment when the nation had to reinvent itself. Not unlike after World War II, plant publics and green spaces once again took up a central role, both symbolically and materially, in naturalizing social bonds and solidifying the nation's cohesion beyond the boundaries of the human skin. This process has proven especially tangible in Berlin's urban fabric. With the fall of the Wall, new regimes of urban and environmental policymaking have transformed the city's material environment, reconstituting it as a national capital and European metropole. For example, the city's landscape program established a network of parks and green corridors as part of the reconstruction plan for a unified Berlin (SenStadt 2014, 22). In addition, the city's nineteenth-century legacies of environmental conservation, the experience of urban breakdown in 1945, and the subsequent political division and deindustrialization during the Cold War created an abundance of open spaces such as parks, city forests, gardens, and urban wastelands. Thus today, even as some of these spaces have been lost to urban development, Berlin is often promoted as "Europe's nature capital” (SenStadt 2014, 3; author's translation), with close to 40 percent of its cityscape comprising green space.

In the past decade, experts have reported on the diversity of the city's fauna and flora despite the endangerment of many species. National media highlight the city's abundant wild life, including foxes, praying mantes, raccoons, ruderal plants such as the tree of heaven, or wild boar roaming the city's green corridors. As a result of global climate change, urban sprawl, increasing traffic, deforestation, overfertilization, and the consolidation of farmland, many animals and plants have made the city their permanent habitat (Riechelmann 2004). Intrigued by this diversity, a variety of publics tending to urban nature proliferate across the city. During Berlin's annual Urban Nature Day, thousands of residents tour the city to discover nature's magic. They follow the tracks of wild boar in the city's forests, listen to the songs of nightingales in parks, or search for herbs growing on sidewalks and in urban wastelands. 


\section{BODIES AND MATTER OUT OF PLACE}

As nature continues to return to the city and Berliners explore the romance of urban wastelands and nonhuman life, debates about immigration and unemployment stress the existence of troubled neighborhoods and a clash of cultures in the city's body. After an initial postunification construction boom in the late 1990s, the city plunged into a fiscal crisis, which coincided with deindustrialization, as well as wide-ranging changes in labor market policies and welfare reform a few years later. Unemployment rates and poverty rose among many Berliners, and the city's Turkish immigrant communities, many of them employed in the manufacturing sector, were negatively affected by these developments (Lanz 2007; Mandel 2008). As in many other cities across Europe, public discourse and policy located the source of these inequalities in migrants themselves, ${ }^{10}$ especially in their presumed lack of economic productivity and sense of disconnection, which leaves traces of dereliction in the urban landscape - for example, by barbecuing in the city's parks and leaving garbage behind. ${ }^{11}$ Metaphors of parallel worlds and social hot spots (soziale Brennpunkte) emphasize a sense of lurking danger: the danger of fire breaking loose, the threat of wilderness imposing itself on the civilized city. In a political climate of austerity and constant suspicion vis-à-vis migrants' unwillingness to integrate, the question of how migrants inhabit nature and the urban environment has become a key site of articulating their racialization and their status as strangers, regardless of actual citizenship status (see also Linke 1999). ${ }^{12}$ Local and national media have painted a gloomy picture of the capital's so-called underclass problem, depicting scenes of wild, unemployed barbecuers

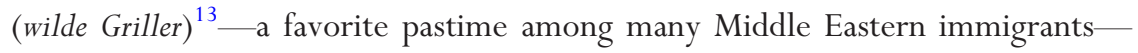
polluting Berlin's green lungs with smoke and garbage. Both the bodies of people of color and their environments, as well as the smoke, meat, and litter they supposedly produce, figure as "matter out of place" (Douglas 2002, 44) in these scenarios. Migrants become almost animal-like, in need of containment.

These tropes of wilderness are more than metaphorical; they inform public policies such as EU-based integration projects that attempt to undo racial segregation, poverty, and urban decay. As Paul Silverstein (2005) has remarked in the case of France, plans to reintegrate Europe's hot spots such as the banlieues, the migrant and working-class suburbs of major French cities, have been likened to the Marshall Plan for rebuilding war-struck Europe, drawing parallels between the ruins of war and Europe's racialized urban peripheries today. Since the fall of 2015, as local bureaucracies have scrambled to accommodate asylum seekers in the face of Europe's so-called refugee crisis, public discourse in Germany at 
first glance seems to have shifted toward a welcoming tone regarding migrants and refugees from the Middle East. Yet a closer look at media coverage reveals an abundance of natural metaphors of waves, tides, and tsunamis of people straining Europe's and the nation's resources, not unlike natural disasters. These scenes of chaos at and within Europe's borders infuse political decisions to distribute and manage asylum seekers' arrivals. Indeed, recent changes to asylum law, which enable faster and more efficient deportations of those considered undeserving, aim precisely at domesticating this seemingly natural force at Europe's gates. As Ghassan Hage (2016) has pointed out, images of ruins, unruly nature, and urban plight in the global North, as well as the porosity of national borders and the widespread sense of embattlement in the context of Europe's migration crisis, express fantasies of colonial reversal that are more than metaphorical. They are occurring at a time when various projects of the governability of our global postcolonial order - such as the nation's efforts to shore up borders and domesticate its others, as well as capitalism's extraction of natural resources - are coming undone.

In this climate of intense debate about nature and migration, Berlin's green spaces, especially its gardens and abandoned lots (Brachen), for many once again provide spaces of hope for escaping social divisions. In recent years, so-called multicultural gardens have proliferated across Berlin and other German cities. By cultivating plants, urban residents hope to overcome cultural barriers and parallel worlds. At the same time, planners, politicians, and many residents advocate gardening as an opportunity for integrating migrants into society: the hope is, through nature, to move past judging or dividing communities. Engaging with plants, people are supposed to identify with their surroundings and to let integration and a genuinely multicultural society grow (Senatsverwaltung für Integration, Arbeit und Soziales 2007). Whereas after the war, rubble plants formed an ambivalent urban ecology amid projects of nation-making, today the cultivation of plants once again serves as the basis for dreams of unifying the nation. The question remains whether, not unlike after the war, contemporary efforts to rehabilitate urban ecologies constitute yet another version of reconstructing the nation through nature and a form of anesthetic greening that glosses over past and present racisms, or whether they are a step toward forging connections across difference that are alert to histories of violence and exclusion in the urban landscape. 


\section{FROM RUINS TO RUBBLE TO A RUDERAL ANALYTIC}

Exploring this question ethnographically, I have employed a ruderal analytic as a guide for both my subject of analysis and my methodology. First, this analytic highlights "ecologies of nationhood" (Comaroff and Comaroff 2001, 625) and draws attention to the ways in which the nation is naturalized and how some human and nonhuman bodies are situated outside the national body. Drawing on recent scholarship on ruins, ${ }^{14}$ a ruderal lens engages a notion of ruination as an active process that shapes "what people are left with" (Stoler 2013, 9). It thus directs focus to the connective tissue that binds human lives to degraded environments, to a lack of access to urban infrastructure, and to racialized inequities such as unemployment in Europe. Yet while ruderal ecologies encompass everyday and nonmemorialized forms of ruination that, like rubble (Gordillo 2014), ${ }^{15}$ are often labeled as insignificant, their story begins with decay_-but does not end with it. As feminist writers have pointed out (e.g., Tsing 2015; Haraway 2016), it is important to go beyond destruction and situate one's analysis in the desire to forge new connections.

While analysts such as Gastón Gordillo (2014) promote rubble as an analytic highlighting forms of destruction that, though invisible, are constitutive of the production of space, a ruderal analytic shifts attention to heterogeneous and unexpected life amid rubble. Ruderal ecologies grow in the inhospitable environments created by war and exclusion; they emerge by chance and entail illegal border crossings - often unnoticed in ethnographies of a city that tend to focus on people, buildings, institutions, or infrastructure. This unruly heterogeneity includes multiple human and nonhuman neighbors that defy a singular focus on ruination or rubble as the end point of social analysis, as well as any easy integration into mononatural or multicultural frameworks. In mutual dialogue with Donna Haraway's (2016) notion of "staying with the trouble" and Anna Tsing's (2012, 96) work on "contaminated diversity" in capitalist ruins, the perspective of ruderal ecologies accounts for the ways in which biological life, cultural identifications, and strategies of survival are never authentic or pure but always situated within histories of disturbance. ${ }^{16}$ Yet while highlighting unplanned takeover and dormant potentials amid capitalism and environmental destruction, as for example Tsing does, a ruderal lens directs focus toward the city and the unruly heterogeneity of life in the ruins of nationalism and racialized exclusions. Osman Kalin's gecekondu, mentioned at the beginning of this essay, offers a case in point. Built in the shadows of a border infrastructure that divided two nations and competing political systems, it takes advantage of an abandoned gap of institutional 
power, unwilling to wait for its assigned place in a country where one never fully belongs. Staging a spontaneous takeover, the gecekondu creates a space of hospitality for people, plants, and objects left behind.

As cultural analysts have begun to recognize human-nonhuman entanglements, thus expanding our analytic lens beyond the human body toward broader vulnerabilities of life, there is a pressing need to be alert to the sticky and persistent ethnoracial politics at work in Europe and beyond. This requires a stronger emphasis on how unruly forms of diversity can easily line up with fantasies of colonial reversal (Hage 2016) or be co-opted by neoliberal projects of profitmaking that celebrate resilience and cultural hybridity (Moore, Kosek, and Pandian 2003; Helmreich 2016). Thinking with feminist and critical race scholars (Agard-Jones 2014; Fortun 2014; Puig de la Bellacasa 2014; Tsing 2015; Haraway 2016; Todd 2016; Hartigan 2017; Myers, forthcoming), a ruderal analytic thus combines an environmental perspective with questions of social justice. Building on the conceptual frameworks of ruins and infrastructure in anthropology and science and technology studies, my research stresses the unintended effects of capitalism, racism, and nation-making as they become embodied in a city's fabric, beyond the boundaries of the human skin. From this perspective, the task is to see ruins or infrastructure not as end goals of analysis but as points of departure for projects that highlight the cosmopolitan more-than-human lives that emerge in cities - and to ask how these set the stage for changing the terms of connectivity in a world shaped by social inequalities and the destruction of environments.

For this very reason, a ruderal analytic seeks out practices and ways of "being alive" (Ingold 2011) that exceed ruination or efforts to create belonging via nature or culture. As the Austrian artist Lois Weinberger indicates, ruderals require a form of "precise inattention" (Kos 2004) — if you are lucky, you catch a quick glance of them on your way to somewhere else. Perhaps it is no surprise that some of the botanists first discovered sticky goosefoot and other ruderals while riding their bikes to work, catching a glimpse of them out of the corner of their eyes. Exploring Berlin's urban ecologies ethnographically thus involves looking for unanticipated human-nonhuman interactions that occur at the edges of the city's infrastructures and that do not adhere to national or capitalist schemes for multicultural gardening and rehabilitating nature.

Rather than posit a universal hybridity of urban wastelands that challenges an emphasis on native species in cultural landscapes (Gandy 2013), ${ }^{17}$ or utilize a notion of (urban) development as ruination or rubble (Gordillo 2014), a ruderal perspective combines science-studies approaches with close-up ethnographic de- 
scription, ${ }^{18}$ and it traces the ways in which humans and nonhumans do not stick to their assigned places amid projects of domestication. Feminist scholars have paved the way methodologically. In times of proliferating nationalisms, racial injustices, degrading infrastructures, toxic environments, and economic precarities, developing methods that allow us to look across scales, shift analytic frameworks, and tell a "rush of stories" (Tsing 2015, 37) becomes paramount. Instead of easily adding up, stories interrupt each other to account for material and social entanglements, gaps, displacements, leakages, and collaborative strategies of survival (Fortun 2012, 2014). Ethnography then becomes a practice of creating connections and hospitable spaces for unexpected intruders. In my work, these have included plants that grow in rubble or the cracks of sidewalks, makeshift urban gardens and informal food economies, or the smoke emanating from "wild barbecuing," as well as other unwieldy uses of urban green space.

With this in mind, let me return to Berlin. Beyond the hedges of publicized and highly regulated nature spaces, such as multicultural gardens or the older tradition of allotment gardens, ${ }^{19}$ less visible and more ephemeral garden practices exist. Their presence begs the question of what kind of human-environment relations are desired in the city, which bodies and lives matter (cf. Butler 1993), and which ones exceed the categories of urban nature that planners and immigration policies have carved out.

\section{THE RABBIT HEATH}

Berlin: a green city? Everyone loves to say it these days. But what is it? It's just a pile of concrete after all.

- Hakim, a gardener

The Hasenheide, or rabbit heath, is a park in the previous border district of Neukölln, adjacent to a mosque and the former city airport Tempelhof. Covering fifty hectares of meadows, the park's landscape is pervaded by traces of urbanization and nationalism - pointing to its transformation from a royal hunting ground (hence the name) to a public gymnastics site and military drill ground in the early twentieth century. After World War II, a seventy-meter-tall rubble hill containing the bombed city's debris was constructed at the park's edges. Today, the Hasenheide is dotted with oak and birch trees and elderberry shrubs. It features a small kiosk, a petting zoo, and an Arabian Nights-themed adventure playground. In the past two decades, the park has also moved to the center of controversies around crime and immigrant drug dealers. Portrayed as a dangerous place in 
national and local media, the park conjures images of escalating battles between bands of Arab and African drug dealers, many of them refugees. Terms such as no-go area used to describe the park reveal the highly racialized public affects that cast the park as off-limits to white German citizens. Concerned, a series of neighborhood groups have initiated events to "take back the park" by caring for its nature, such as a leaf-raking day or the construction of a new nature trail. Wild barbecuing has been banned altogether.

Despite the media flurry, there is a small corner of the park invisible to local authorities, situated between bushes and adjacent to a meadow of sunbathing German nudists. Cultivated by a group of friends and former coworkers, this secret garden features fruit trees, sunflowers, tomatoes, strawberries, cucumbers, mint, peppers, and a few nettles in between. Hidden in the shrub, there is also a barbecue. The gardeners, all men in their late fifties to seventies, live nearby and come to the park every day, bringing food, plants, drinks, and card games. The gardeners all migrated from rural Anatolia to Berlin in the 1960s and 1970s, when Turkey signed contracts with West Germany to tackle unemployment and send migrant workers to cities like Berlin to continue to rebuild the country and boost Germany's economy from the ruins of war. When Hakim arrived in Berlin in 1969, he was assigned a few square meters of living space in the city's migrant barracks. ${ }^{20}$ In the following decades, the West German government did not recognize Germany as a country of immigration (Mandel 2008) and Hakim, like many other Turkish Berliners, continued to be perceived as a temporary guest worker.

Hakim felt he had paid a high price, working jobs that required strenuous physical labor. Many of his colleagues depended on walking aids or wheelchairs and suffered severe physical impairments at a relatively early age. Indeed, due to hard physical labor and environmentally hazardous working conditions, the rates for early retirement and disability among Turkish immigrants have proven disproportionately high (Lüneburg 2006). Hakim worked for an electronics company assembling adapters, but due to a chronic neck injury from years of repetitive manual labor, he, like Osman Kalin, had to retire early. Widowed, he went to the park to meet friends instead of sitting at home-friends like Kadir, who had recently lost his eyesight during a work accident. According to Hakim, they began cultivating the garden because "we were here all the time anyway." It must have been Erol, they recall. Bored, he started moving the earth back and forth one day as he sat on the bench chatting with others. In fact, Erol claims that he accidentally dropped some sunflower seeds and they sprouted. In Turkish these 
seeds are called ayçekirdeği, a favorite snack of which one can see traces across Berlin's sidewalks.

While Hakim saw Berlin as a pile of rubble and concrete, he considered their garden to be the antithesis of that. Going there, he was able to breathe. His friends called it "Maria Mama," because someone had found a marble figure resembling Maria, the mother of Jesus, and placed it in the middle of the vegetable bed. Maria Mama was in constant flux: people kept adding tomato seedlings, brought seeds sent from Turkey, and ripped out dead plants. But most of all, the garden was a nursery for withering plants: everyone brought plants they did not need, or that were doing badly on apartment windowsills. Yet altogether, Maria Mama was a failure - at least according to its caretakers. One day, someone stole the apple tree. Then the figure of Maria Mama disappeared. Now a pink stuffed rabbit replaced it. Worse yet, with increasingly hot and dry summers in recent years, the soil was not fertile enough and water supply was scarce. Hakim had struck up a deal with the owner of the nearby kiosk to use the faucet, but carrying the water across the park proved a tedious business. Still, he was hopeful: he dreamed that strawberries would cover the entire meadow the following year.

Not unlike Osman Kalin's gecekondu garden, Maria Mama constitutes a ruderal ecology: it fills a gap not only in between the city's landscaped meadows and exclusionary environments of nation-making but also in Hakim's life. In both gardens, we see that ruderal ecologies are not necessarily characterized by an absence of cultivation: human-plant relations are shaped by systems of control, and yet their interactions also create unruly openings for new forms of cohabitation (see also Myers, forthcoming) that do not adhere to the places assigned to them in official definitions of public space, private property, and multiculturalist schemes. It is in this sense that they carry seeds of change.

At first glance, Maria Mama might look like an object of nostalgia, an ephemeral project of elderly men who have become superfluous - if it is visible to anyone at all. And yet, the men's relation to their environment and their cultivation practices sit squarely among contemporary celebrations of urban nature and multiculturalist efforts to integrate immigrants, who are racially cast as other, via the care for plants. Instead of waiting to be granted a costly garden unit, the gardeners of Maria Mama took over space and created a sociality of neighbors and coworkers in the absence of work and access to public resources. 
Cobbled together of withering plants, thrown-away seeds, and clandestine access routes to public water supplies, Maria Mama's cultural and material fabric is far from authentic. In fact, when I asked the gardeners, they seemed rather indifferent to whether this was a Turkish or religious garden. After all, once it was stolen, the figure of Maria was quickly replaced by a pink rabbit. Providing a space of hospitality for flailing plants, found objects, and chance encounters, they instead created a fragile garden ecology that, far from value-free nature or anesthetic greening, exposes histories of damage and makes viable what has been left behind. In our conversations, Kadir, Erol, and Hakim all recounted experiences of being marked as culturally and physically other in German society. They commented on how their life trajectories had been deeply shaped by layers of racialization and exclusion - ranging from the exploitation of cheap foreign labor embedded in the logic of guest-worker contracts, to the health and body screenings as they were recruited to Germany, to the racist discrimination that they experienced in the labor and housing market in Berlin. Their everyday lives were full of reminders of their continued status as suspect strangers in a city and country that, although having begun to recognize them as part of the nation's multicultural fabric, continues to deny them full citizenship and for several decades has cast them as guests soon to return "home." ${ }^{21}$ Perhaps, though, it was Hakim's remark about Berlin being less of a green city than a city of rubble that best captures a sense of ruination and damage in the face of multiple layers of exclusion experienced both in their lives and their relation to the city's material environment.

As Frantz Fanon $(1963,250)$ remarked, racial and imperial formations are forms of power that sow seeds of ruination in bodies and psyches, but also in landscapes, sensibilities, and things (see also Stoler 2013, 9-10). ${ }^{22}$ Similarly, applying a ruderal analytic to Maria Mama, as well as to the gecekondu and other sites across Berlin, can reveal histories of damage inflicted onto bodies, affects, and environments. Yet the ruderal lens I promote in this essay also illustrates that humans and nonhumans have the capacity to create openings for new collaborations that challenge contemporary multiculturalist agendas and their invocations of nature by actually reworking the fallout from past exclusion, exploitation, or violence. $^{23}$

At a historical moment when not only the bodies of Middle Eastern immigrants are coded as other, suspect of being unwilling to integrate, but also their relation to the urban environment is framed as unruly, under scrutiny for leaving traces of dereliction or posing a threat, Maria Mama's gardeners challenge their positioning as out of place. In their own words, they have created a space to 
"breathe." A project of recuperation of both plants and people, Maria Mama, like the gecekondu garden, exposes the frailties of ruderal ecologies and projects that challenge urban nature as defined by private property and urban planners - projects in which people, plants, and seeds follow the traces of human communication and injury, and in turn inspire action to forge new socialities. Although it may have been a failure the year I visited, Maria Mama's seeds are lying dormant in the ground, waiting to remake alternative ecologies of belonging out of Europe's ruins of ethnic division and racism.

\section{CONCLUSION}

As analysts in anthropology and beyond have turned to new materialisms and multispecies relations, we have sharpened our understanding of earthly entanglements and the in/stability of structures such as technological networks, urban environments, access to material resources, and other forms of governance. Yet this may come at the risk of eclipsing the volatility of violence and the viscosity of social injustice - also among humans (Bauer and Bhan 2016). Anthropologists' recent attention to infrastructure, ruins, and rubble grapples with this caveat. In times of increased racism, displacement, war, and the loss of hospitable environments for both humans and nonhumans, engagements with urban materialities face the challenge of more explicitly mapping the mechanisms that shape what lives come to flourish amid the disturbed environments of our time.

In this essay, I have proposed a ruderal perspective to tackle this challenge and to sharpen recognition of the politics at stake in emerging urban ecologies. Bringing together questions of migration and social justice with environmental perspectives, I have engaged different instances of remaking urban nature in Berlin. In the encounter between media, scientists, and rubble plants, as well as Turkish Berliners and their gardens, the lens of the ruderal guides me to look for the city's unintended ecologies as these emerge in the ruins of nation-making, war, displacement, xenophobia, environmental change, and contemporary austerity policies. As I have shown, this entails three analytical moves.

First, a ruderal lens takes rubble and ruination as points of departure to examine the (after)lives of racial exclusions, economic collapse, and interrupted futures (Stoler 2013) embedded in urban environments. While ethnographically tracing the multiple historical layers of capitalist, colonial, and environmental destruction (Gordillo 2014) that reside in urban landscapes, the perspective I propose also goes a step further: it draws attention to unruly forms of embodiment among strangers, both human and nonhuman, and thus to persistent ecologies in 
a city's inhospitable environments. In this regard, a ruderal perspective also responds to a gap in scholarship on ruins, which is often crowded with images of rubble overgrown with weeds yet rarely describes or theorizes its actual ecologies, even as some scholars highlight the afterlife of ruins. Following stories about rubble, gardens, and other human-environment relations in the city thus also means looking at how the ruins of contemporary capitalism and nation-making become our very habitats.

Second, a ruderal analytic examines how social inequalities and histories of race and nationhood work through human-nonhuman relations in sticky and persistent ways. Doing so, it provides a lens for integrating ecological perspectives into an urban context while highlighting questions of social justice. As I have shown, relations between people, plants, seeds, and environments are deeply shaped by the history of nationhood in Berlin. Yet the human-plant socialities I have described do not adhere to those envisioned in the city's shiny brochures on multicultural gardening. Instead of fitting into categories of urban nature and gardening for (national) integration, the Berlin gecekondu and Maria Mama grow in the gaps - not only of the city's landscaped meadows or other infrastructure but also in people's lives and in an inhospitable environment that suspects TurkishGermans of not integrating into German society. As I have shown, these practices are not a simple, happy survival amid ruins, nor are they free of power. Rubble plants grow from seeds carried on the boots of migrants and refugees, and they may remain dormant potentials in a city's fabric. Glanced over or viewed as insignificant side effects of more solid urban infrastructures and institutions, it remains an open question as to whether or not they enable flourishing.

Third, while I have focused on human-plant relations in the more narrow sense, a ruderal lens considers a notion of ecology not as "a naturalization of politics - as if one wanted to 'treat humans like plants or animals," but as "the recognition of the immense complexity involved for any entity-human or nonhuman - to have a voice, to take a stand, to be counted, to be represented, to be connected with others" (Latour and Weibel 2005, 458-59). Hence it opens up cultural analysis to a wider field of human-nonhuman relationalities (see Descola 2013) while asking about the power at stake in shaping what lives thrive in the disturbed landscapes we inhabit. The history of postwar rubble plants illustrates the layered histories of this process. In an effort to do justice to these layerings, I have put together seemingly disparate stories - stories of West Berlin botanists researching rubble plants and Turkish men planting gardens at the side of parks or in between walls. Following a ruderal method that utilizes shifting 
frameworks (Fortun 2012, 2014) and a "rush of stories" (Tsing 2015, 37), I argue, accounts for the ways in which urban ecologies, globalization, and racial exclusions are entangled with one another. Such a practice pushes anthropological inquiry beyond a singular focus on homogeneous entities of particular ethnic communities, systems of kinship, formal economies, institutions, built environments, or even the Anthropocene (see Bauer and Bhan 2016). Rather than simply expand the realm of urban society to include the nonhuman, this essay therefore promotes a strategy of exploring how multispecies relations give rise to new socialities and connections, including among humans (Hinchliffe et al. 2005; Hinchliffe and Whatmore 2006), that work against a city's divisions. As I have shown, rubble plants, botanists, immigrants and their gardens are implicated in the dynamics of capitalism, nationalism, and war in disparate and yet deeply connected ways. I thus argue that if we want to imagine a future of social and environmental justice in cities, or what AbdouMaliq Simone (2004) has called a "city yet to come," we need to attend to the ways in which these unlikely neighbors inhabit and traverse the domesticated - and ruined-landscapes that make up cities today.

\section{ABSTRACT}

Engaging with a series of human-plant encounters in Berlin, this article explores possibilities for rethinking the heterogeneity of urban life in the ruins of European nationalism and capitalism. Drawing on ethnographic fieldwork and revisiting Berlin's postwar history of botanical research, I develop the concept of the ruderal and expand it for an anthropological inquiry of urban life. The term ruderal was originally used by Berlin ecologists after the Second World War to refer to ecologies that spontaneously inhabit disturbed environments: the spaces alongside train tracks or roads, wastelands, or rubble. Exploring Berlin as a ruderal city, I direct attention to the often unnoticed, cosmopolitan, and unruly ways of remaking the urban fabric at a time of increased nationalism and ecological destruction. Tracing human-plant socialities in encounters between scientists and rubble plants, in public culture, and among immigrants and their makeshift urban gardens, the lens of the ruderal directs ethnographic analysis toward the city's unintended ecologies as these are produced in the context of nation-making, war, xenophobia, migration, environmental change, and contemporary austerity policies. Attending to ruderal worlds, I argue, requires telling stories that do not easily add up but that combine environmental perspectives with the study of migration, race, and social inequality - in the interest of mapping out possibilities for change. This framework thus expands a recent anthropological focus on ruins, infrastructure, and urban landscapes by highlighting questions of social justice that are at stake in emerging urban ecologies and an era of inhospitable 
environments. [ruins; cities; urban ecology; plants; infrastructure; landscape; migration, nationalism; race; Europe; Germany]

\section{NOTES}

Acknowledgments I could not have written this article without the immense generosity of my informants in Berlin, most of whom remain anonymous here. With their insights and creativity, they taught me a different way of seeing the city. I am particularly grateful to Herbert Sukopp for inspiring me to consider ruderal plants and for helping me sharpen my understanding of Berlin's urban ecologies. I am indebted to the intellectual communities of which I have been fortunate to be part in the past years. Special thanks go to Jason Alley, Nikhil Anand, Mark Anderson, Fadi Bardawil, Amahl Bishara, Julie Chu, James Clifford, Ian Condry, Jeffry Diefendorf, Amah Edoh, Catherine Fennell, Michael Fisch, Matthew Gandy, Donna Haraway, Stefan Helmreich, Eleana Kim, Kristina Lyons, Andrew Mathews, Natasha Myers, Damani Partridge, Bruno Perreau, Lisa Rofel, Anna Tsing, Noah Tamarkin, Armanc Yildiz, Austin Zeiderman, and Asli Zengin, who have commented on drafts and ideas at various stages. The argument in this essay also benefited tremendously from feedback received in a series of workshops, including the Infrastructure Reading Group at the University of Chicago, the STS Circle at Harvard University, the Matters of Urban Citizenship Workshop at Columbia University, the Military Ecologies Workshop at the University of California, Irvine, the Infrastructural Worlds Workshop at Duke University, the Anthropocene Campus at the Haus der Kulturen der Welt in Berlin, and the Chronopolis Symposium in the Department for Germanic Languages and Literatures at the University of Michigan. My gratitude also goes to the anonymous reviewers for their detailed and productive comments, as well as to Dominic Boyer and the Cultural Anthropology editorial team for their guidance throughout the revision process. Research and writing for this article were supported by the Andrew W. Mellon/ACLS Dissertation Completion Fellowship, a University of California, Santa Cruz Chancellor's Dissertation Year Fellowship, and a fieldwork grant by the Wenner-Gren Foundation.

1. Gecekondu is a combination of the Turkish words gece (night) and kondu (placed). Taking advantage of legal loopholes, gecekondu emerged in connection with rural migration to Turkish cities beginning in the 1950s, sometimes literally popping up overnight. Many Turkish Berliners, like Osman, lived in them before migrating to Berlin (Lanz 2007). In contrast to the Turkish gecekondu, the Berlin version did not serve as the main residence for Osman's family. For a survey of the literature on gecekondu and changing representations of rural migrants as "other" in Turkey, see Erman 2001.

2. Forms of disturbance range from vegetation removal and uses of herbicide to drought, fire, and soil erosion (Grime 1977).

3. While this shift has challenged anthropocentric social analyses, humans often continue to appear as key agents of the consequences of their structures of design. In this moment of self-reflection, there is remarkably little reference to earlier forms of reflexivity, such as the Writing Culture moment or feminist and postcolonial critiques that highlight racialized and gendered intersections of language, power, and embodiment (Fortun 2012; Helmreich 2014).

4. For a discussion of ruination as a concept that captures the paradoxical nature of infrastructure as productive and destructive, see Howe et al. 2016.

5. Following Matthew Gandy (2006), I thus use the term urban nature in two senses, referring to the ecological dynamics and material transformation of cities as well as to shifting ecological imaginaries about the city.

6. For an ethnographic account of the contextual politics of classificatory practices around alien species, see Helmreich 2005.

7. Furthermore, the composition, associations, and succession schemes of ruderal sites did not easily fit into the scientists' rectangular sample areas, nor the classificatory schemes of adventive floristics and phytosociology (Lachmund 2003, 248).

8. Alliances between scientists and citizens, as well as Sukopp's role as Berlin's commis- 
sioner for nature protection and advisor to the State Office for Environmental Protection since the 1970s, helped pave the way for the conservation of urban wastelands such as the Schöneberger Südgelände, an abandoned switchyard for trains (Kowarik, Starfinger, and Trepl 1995; Lachmund 2013).

9. Mary Douglas $(2002,47)$ describes stickiness and viscosity as concepts that alert us to the properties of matter and embodied interrelations between self and the world.

10. In Germany, the categories of immigrant and migrant are highly contested, historically contingent subject positions that are deeply entangled with racialized notions of German citizenship. In this article, I use the terms immigrant and migrant to refer to the subject positions produced in public discourse and policymaking, and also to first-generation Turkish-German immigrants. In contrast, I use the terms Turkish-German or Turkish Berliner to refer to both immigrants and the descendants of immigrants from Turkey.

11. See, for instance, Thilo Sarrazin's (2010) controversial book Deutschland schafft sich selbst $a b$.

12. Emphasizing the enduring power of race and racism in Europe and its historical specificity (see Gilroy 2004), I understand race to not have an intrinsic, fixed meaning but to articulate with the politics of nature, nation, class, gender, and ideas of bodily difference in historically contingent ways. Racial formations thus constitute a "body politic" (Brown 2005, 72) that marks inner selves, social bodies, and environmental milieus and goes beyond the boundary of the human skin (cf. Hartigan 2017).

13. On the racialization of barbecuing as a "savage" or "wild" practice, see Stoetzer 2014.

14. Recent work has also examined how ruins capture national imaginations and emerge as a central element of nuclear nationalism (Masco 2008), or as affective attachments of Cold War urban restructuring and (post)socialist citizenship (Schwenkel 2013).

15. In contrast to ruins, rubble is often considered formless material without value, and hence it is not memorialized (Simmel 1983; Puff 2010).

16. Tracking matsutake worlds in Oregon's forests, Tsing $(2015,97)$ identifies a shift in cultural identifications among Asian American immigrants: while many adopted a framework of assimilation immediately following World War II, contemporary cultural practices are often routed through heterogeneous memories of war or narratives of freedom.

17. Wastelands is an ambivalent term that, like rubble, connotes lack of value within a capitalist economy (Gandy 2013). Neither are inherently progressive: they are not immune to commodification, and their hybridity can signal extinction, exclusion, and racial violence.

18. See Tsing $(2015,159)$ for a critique of the focus on concepts in science studies, at the cost of careful ethnographic and historical storytelling.

19. Allotment gardens (Schrebergärten) originally served as a source of food and as leisure space for the urban working classes in the nineteenth century. Icons of national identity and still abundant in many German cities today, these gardens follow intricate sets of rules that prescribe their size and design, as well as the composition of (often native) flowers and vegetables. Although never free of power, ruderal sites differ from allotment gardens (and multicultural gardens) because they adhere less neatly to boundaries of nationhood, culture, property or other institutionalized human-nonhuman relations.

20. Turkish migrant workers comprised West Berlin's largest immigrant community. For a discussion of East-West developments and housing policies, see Çağlar and Soysal 2003, Lanz 2007, and Mandel 2008.

21. See also Damani Partridge's (2012) analysis of the simultaneity of exclusion and inclusion and the racialization of citizenship in Germany.

22. For Fanon $(1963,249-50)$, any struggle of liberation therefore has to root out imperial and racial formations from both the land and people's minds and bodies.

23. See Paul Gilroy's (2004) critique of mainstream multiculturalism and its denial of already existing forms of unruly conviviality in urban centers across Europe. 


\section{REFERENCES}

Agard-Jones, Vanessa

2014 “Spray." Somatosphere, May 27. http://somatosphere.net/2014/05/spray.html. Anand, Nikhil

2017 Hydraulic City: Water and the Infrastructures of Citizenship in Mumbai. Durham, N.C.: Duke University Press.

Bauer, Andrew, and Mona Bhan

2016 "Welfare and the Politics and Historicity of the Anthropocene." South Atlantic Quarterly 115, no. 1: 61-85. https://doi.org/10.1215/00382876-3424753.

Bennett, Michael, and David W. Teague, eds.

1999 The Nature of Cities: Ecocriticism and Urban Environments. Tucson: University of Arizona Press.

Brantz, Dorothee, and Sonja Dümpelmann, eds.

2011 Greening the City: Urban Landscapes in the Twentieth Century. Charlottesville: University of Virginia Press.

Brown, Jacqueline

2005 Dropping Anchor, Setting Sail: Geographies of Race in Black Liverpool. Princeton, N.J.: Princeton University Press.

Bruun Jensen, Caspar, and Atsuro Morita

2017 "Introduction: Infrastructure as Ontological Experiments." Ethnos 82, no. 4: 615-26. https://doi.org/10.1080/00141844.2015.1107607.

Butler, Judith

1993 Bodies that Matter: On the Discursive Limits of "Sex". New York: Routledge.

Çağlar, Ayşe, and Levent Soysal

2003 "Introduction: Turkish Migration to Germany-Forty Years After." New Perspectives on Turkey 29, Spring/Fall: 1-18. https://doi.org/10.1017/ S0896634600006087.

Carse, Ashley

2012 "Nature as Infrastructure: Making and Managing the Panama Canal Watershed." Social Studies of Science 42, no. 4: 539-63. https://doi.org/10.1177/ 0306312712440166.

Chakrabarty, Dipesh

2012 "Postcolonial Studies and the Challenges of Climate Change." New Literary History 43, no. 1: 1-18. https://doi.org/10.1353/nlh.2012.0007.

Chalfin, Brenda

2014 "Public Things, Excremental Politics, and the Infrastructure of Bare Life in Ghana's City of Tema." American Ethnologist 41, no. 1: 92-109. https://doi.org/ 10.1111 /amet. 12062 .

Comaroff, Jean, and John L. Comaroff

2001 "Naturing the Nation: Aliens, Apocalypse, and the Postcolonial State." Journal of Southern African Studies 27, no. 3: 627-51. https://doi.org/10.1080/ 13504630120065301.

Cronon, William

1992 Nature's Metropolis. Chicago and the Great West. New York: W.W. Norton.

Davis, Mike

2002 Dead Cities, and Other Tales. New York: The New Press.

Dawdy, Shannon Lee

2010 "Clockpunk Anthropology and the Ruins of Modernity." Current Anthropology 51, no. 6: 761-93. https://doi.org/10.1086/657626.

de la Cadena, Marisol

2015 Earth Beings: Ecologies of Practice across Andean Worlds. Durham, N.C.: Duke University Press.

Descola, Philippe

2013 Beyond Nature and Culture. Translated by Janet Lloyd. Chicago: University of Chicago Press. Originally published in 2005. 
Diefendorf, Jeffry M.

1993 In the Wake of War: The Reconstruction of German Cities after World War II. New York: Oxford University Press.

Douglas, Mary

2002 Purity and Danger: An Analysis of Concepts of Pollution and Taboo. New York: Routledge. Originally published in 1966.

Erman, Tahire

2001 "The Politics of Squatter (Gekecondu) Studies in Turkey: The Changing Representations of Rural Migrants in the Academic Discourse.” Urban Studies 38, Fanon, Frantz

no. 7: 983-1002. https://doi.org/10.1080/00420980120080131.

1963 The Wretched of the Earth. Translated by Constance Farrington. New York: Grove Press. Originally published in 1961.

Fennell, Catherine

2015 Last Project Standing: Civics and Sympathy in Post-Welfare Chicago. Minneapolis: University of Minnesota Press.

Fortun, Kim

2012 "Ethnography in Late Industrialism." Cultural Anthropology 27, no. 3: 446-64. https://doi.org/10.1111/j.1548-1360.2012.01153.x.

2014 "From Latour to Late Industrialism." HAU 4, no. 1: 309-329. https://doi.org/ 10.14318/hau4.1.017.

Gandy, Matthew

2006 "Urban Nature and the Ecological Imaginary." In The Nature of Cities: Urban Political Ecology and the Politics of Urban Metabolism, edited by Nik Heynen, Maria Kaika, and Erik Swyngedouw, 63-74. New York: Routledge.

2013 "Marginalia: Aesthetics, Ecology, and Urban Wastelands." Annals of the Association of American Geographers 103, no. 6: 1301-1306. https://doi.org/10.1080/ 00045608.2013 .832105$.

Gilroy, Paul

2004 After Empire: Melancholia or Convivial Culture? New York: Routledge.

Gordillo, Gastón R.

2014 Rubble: The Afterlife of Destruction. Durham, N.C.: Duke University Press.

Grime, J. P.

1977 "Evidence for the Existence of Three Primary Strategies in Plants and Its Relevance for Ecological Theory.” American Naturalist 111, no. 982: 1169-94. Gupta, Akhil https://doi.org/10.1086/283244.

2013 "Ruins of the Future." Paper presented at the Annual Meeting of the American Hage, Ghassan

Anthropological Association, Chicago, Ill., November 23.

2016 “État de siège: A Dying Domesticating Colonialism?" American Ethnologist 43, no. 1: 38-49. https://doi.org/10.1111/amet.12261.

2017 Is Racism an Environmental Threat? Malden, Mass.: Polity Press.

Haraway, Donna

1992 "Otherworldly Conversations, Terran Topics, Local Terms." Science as Culture 3, no. 1: 64-98. https://doi.org/10.1080/09505439209526336.

2016 Staying with the Trouble: Making Kin in the Chthulucene. Durham, N.C.: Duke

Harms, Erik University Press.

2013 "Eviction Time in the New Saigon: Temporalities of Displacement in the Rubble of Development." Cultural Anthropology 28, no. 2: 344-68. https://doi.org/ 10.1111/cuan.12007.

Hartigan, John, Jr.

2017 Care of the Species: Races of Corn and the Science of Plant Biodiversity. Minneapolis: University of Minnesota Press. 
Helmreich, Stefan

2005 “How Scientists Think; About 'Natives,' For Example: A Problem of Taxonomy among Biologists of Alien Species in Hawaii." Journal of the Royal Anthropological Institute 11, no. 1: 107-128. https://doi.org/10.1111/j.1467-9655.2005. 00228.x.

2014 "The Left Hand of Nature and Culture." HAU 4, no. 3: 373-81. https:// doi.org/10.14318/hau4.3.024.

2016 "The Mushroom at the End of the World. On the Possibility of Life in Capitalist Ruins.” Book review. American Ethnologist 43, no. 3: 570-72. https://doi.org/ 10.1111 /amet. 12356 .

Heynen, Nik, Maria Kaika, and Erik Swyngedouw, eds.

2006 In the Nature of Cities: Urban Political Ecology and the Politics of Urban Metabolism. New York: Routledge.

Hinchliffe, Steve, Matthew B. Kearnes, Monica Degen, and Sarah Whatmore

2005 "Urban Wilds: A Cosmopolitical Experiment." Environment and Planning D 23, no. 5: 643-58. https://doi.org/10.1068/d351t.

Hinchliffe, Steve, and Sarah Whatmore

2006 "Living Cities: Toward a Politics of Conviviality." Science as Culture 15, no. 2: 123-38. https://doi.org/10.1080/09505430600707988.

Howe, Cymene, et al.

2016 "Paradoxical Infrastructures: Ruins, Retrofit, and Risk.” Science, Technology, and Human Values 41, no. 3: 1-19. https://doi.org/10.1177/0162243915620017.

Ingold, Tim

2011 Being Alive: Essays on Movement, Knowledge, and Description. New York: Routledge. Johnson, Andrew Alan

2013 "Progress and Its Ruins: Ghosts, Migrants, and the Uncanny in Thailand.” Cultural Anthropology 28, no. 2: 299-319. https://doi.org/10.1111/cuan.12005.

Kos, Alfred

2004 "Lois und Franziska Weinberger." Exhibition text, evn collection. http://www. evn-sammlung.at/asp/asp/showwerk2 . asp?lang $=$ en\&werkid $=91$ \&persid $=49$.

Kowarik, Ingo, Uwe Starfinger, and Ludwig Trepl, eds.

1995 Dynamik und Konstanz: Festschrift für Herbert Sukopp. Bonn-Bad Godesberg,

Lachmund, Jens
Dynamik und Konstanz: Festschrift für
Germany: Bundesamt für Naturschutz.

2003 "Exploring the City of Rubble: Botanical Fieldwork in Bombed Cities in Germany after WWII.” Osiris 18: 234-54. https://doi.org/10.1086/649386.

2013 Greening Berlin. The Co-Production of Science, Politics, and Urban Nature. Cambridge, Mass.: MIT Press.

Lanz, Stephan

2007 Berlin aufgemischt: Abendländisch-multikulturell-kosmopolitisch? Die politische Konstruktion einer Einwanderungsstadt. Bielefeld, Germany: transcript Verlag.

Larkin, Brian

2013 “The Politics and Poetics of Infrastructure." Annual Review of Anthropology 42: 327-43. https://doi.org/10.1146/annurev-anthro-092412-155522.

Latour, Bruno

2013 An Inquiry into Modes of Existence: An Anthropology of the Moderns. Translated by Catherine Porter. Cambridge, Mass.: Harvard University Press.

Latour, Bruno, and Peter Weibel

2005 "The Parliament of Nature." In Making Things Public: Atmospheres of Democracy, edited by Bruno Latour and Peter Weibel, 458-59. Cambridge, Mass.: MIT Press.

Le Guin, Ursula K.

1989 “A Carrier-Bag Theory of Fiction." In Dancing at the Edge of the World: Thoughts on Words, Women, Places, 165-70. New York: Grove.

Linke, Uli

1999 German Bodies: Race and Representation After Hitler. New York: Routledge. 
Lowrie, Ian, with Dominic Boyer

2014 "Dominic Boyer on Anthropology of Infrastructure." Platypus, March 3. http:/ /blog.castac.org/2014/03/dominic-boyer-on-the-anthropology-ofinfrastructure.

Lüneburg, Anja

2006 "Gesundheitliche Situation und zukünftiger Versorgungsbedarf von älteren türkischen Arbeitsmigranten.” Thesis, Program in Ecotrophology, Hamburg University of Applied Sciences.

Mandel, Ruth

2008 Cosmopolitan Anxieties: Turkish Challenges to Citizenship and Belonging in Germany. Durham, N.C.: Duke University Press.

Masco, Joseph

2008 “'Survival is Your Business': Engineering Ruins and Affect in Nuclear America." Cultural Anthropology 22, no. 2: 361-98. https://doi.org/10.1111/j.15481360.2008.00012.x.

Moore, Donald S., Jake Kosek, and Anand Pandian, eds.

2003 Race, Nature, and the Politics of Difference. Durham, N.C.: Duke University Press. Myers, Natasha

Forthcoming "From Edenic Apocalypse to Gardens of Eden: Plants and People in and after the Anthropocene." In Infrastructure, Environment, and Life in the Anthropocene, edited by Kregg Hetherington. Durham, N.C.: Duke University Press.

Navaro-Yashin, Yael

2012 The Make-Believe Space: Affective Geography in a Postwar Polity. Durham, N.C.: Duke University Press.

Partridge, Damani J.

2012 Hypersexuality and Headscarves: Race, Sex, and Citizenship in the New Germany. Bloomington: Indiana University Press.

Puig de la Bellacasa, María

2014 "Encountering Bioinfrastructures: Ecologies of Struggle and the Sciences of Soil." Social Epistemology 28, no. 1: 26-40. https://doi.org/10.1080/02691728. 2013.862879.

Puff, Helmut

2010 "Ruins as Models: Displaying Destruction in Postwar Germany." In Ruins of Modernity, edited by Julia Hell and Andreas Schönle, 253-69. Durham, N.C.: Duke University Press.

Rademacher, Anne, and K. Sivaramakrishnan, eds.

2013 Ecologies of Urbanism in India: Metropolitan Civility and Sustainability. Hong Kong: Hong Kong University Press.

Riechelmann, Cord

2004 Wilde Tiere in der Grosstadt. Berlin: Nicolaische Verlagsbuchhandlung.

Sarrazin, Thilo

2010 Deutschland schafft sich $a b$. Munich, Germany: dva.

Schwenkel, Christina

2013 "Post/Socialist Affect: Ruination and Reconstruction of the Nation in Urban Vietnam." Cultural Anthropology 28, no. 2: 252-77. https://doi.org/10.1111/ cuan. 12003.

Sebald, W. G.

2004 On the Natural History of Destruction. New York: Modern Library.

Senatsverwaltung für Integration, Arbeit, und Soziales

2007 "Berlin: Haupstadt der interkulturellen Gärten.” Press release, August 24. https://www.berlin.de/rbmskzl/aktuelles/pressemitteilungen/2007/ pressemitteilung.56516.php.

SenStadt

2014 “Strategie Stadtlandschaft Berlin: natürlich, urban, produktiv." Berlin: Senatsverwaltung für Stadtentwicklung und Umwelt. https://www.berlin.de/ senuvk/umwelt/landschaftsplanung/strategie_stadtlandschaft. 
Silverstein, Paul A.

2005 "Immigrant Racialization and the New Savage Slot: Race, Migration, and Immigration in the New Europe." Annual Review of Anthropology 34: 363-84. Simmel, Georg https://doi.org/10.1146/annurev.anthro.34.081804.120338.

1983 “Die Ruine.” In Philosophische Kultur, 118-24. Berlin: Klaus Wagenbach. Originally published in 1919.

Simone, AbdouMaliq

2004 For the City Yet to Come: Changing African Life in Four Cities. Durham, N.C.: Duke University Press.

Stoetzer, Bettina

2014 "Wild Barbecuing: Urban Citizenship and the Politics of (Trans-)Nationality in Berlin's Tiergarten." In Transnationalism and the German City, edited by Jeffry Stoler, Ann Laura

Diefendorf and Janet Ward, 73-86. New York: Palgrave Macmillan.

2013 “The Rot Remains': From Ruins to Ruination.” In Imperial Debris. On Ruins and Ruination, edited by Ann Laura Stoler, 1-35. Durham, N.C.: Duke University Press.

Sukopp, Herbert

2003 Rückeroberung? Natur im Grossstadtbereich. Vienna: Picus.

2007 "Rückeroberung? Natur in der Grosstadt.” Denkanstösse, February 5: 57-70.

2008 "On the Early History of Urban Ecology in Europe." In Urban Ecology: An International Perspective on the Interaction between Humans and Nature, edited by John M. Marzluff, Eric Schulenberger, Wilfried Endlicher, Marina Alberti, Gordon Bradley, Clare Ryan, Craig ZumBrunnen, and Ute Simon, 79-97. New York: Springer.

Sukopp, Herbert, and Angelika Wurzel

2003 "The Effects of Climate Change on the Vegetation of Central European Cities." Urban Habitats 1, no. 1: 66-86. http://www.urbanhabitats.org/v01n01/ climatechange_full.html.

Todd, Zoe

2016 “An Indigenous Feminist's Take on the Ontological Turn: 'Ontology' is Just Another Word for Colonialism.” Journal of Historical Sociology 29, no. 1: 4-22. https://doi.org/10.1111/johs.12124.

Tsing, Anna

2012 “Contaminated Diversity in 'Slow Disturbance': Potential Collaborators for a Livable Earth." In "Why Do We Value Diversity? Biocultural Diversity in a Global Context," edited by Gary Martin, Diana Mincyte, and Ursula Münster, 95-97. RCC Perspectives, no. 9. https://doi.org/10.5282/rcc/5599.

2015 The Mushroom at the End of the World: On the Possibility of Life in Capitalist Ruins. Princeton, N.J.: Princeton University Press.

Viveiros de Castro, Eduardo

2012 "Immanence and Fear: Stranger-Events and Subjects in Amazonia." HAU 2, no. 1: 27-43. https://doi.org/10.14318/hau2.1.003.

von Schnitzler, Antina

2013 "Traveling Technologies: Infrastructure, Ethical Regimes, and the Materiality of Politics in South Africa." Cultural Anthropology 28, no. 4: 670-93. https://

Williams, Raymond doi.org/10.1111/cuan.12032.

1973 The Country and the City. New York: Oxford University Press.

Wolch, Jennifer

1998 “Zoopolis." In Animal Geographies: Place, Politics and Identity in the Nature-Culture Borderlands, edited by Jennifer Wolch and Jody Emel, 119-38. New York: Verso. 